\title{
BIOHYDROGEN PRODUCTION IN AnSBBR IN FED-BATCH FROM STARCH EFFLUENT: INFLUENCE OF ORGANIC LOAD
}

\author{
Tamiris U. Tonello ${ }^{1 *}$, Cristiane L. Andreani ${ }^{2}$, Angelo G. Mari ${ }^{3}$, José R. Fernandes ${ }^{3}$, Simone D. Gomes ${ }^{3}$ \\ 1*Corresponding author. State University of West Paraná/ Cascavel - PR, Brasil. E-mail: uana_@hotmail.com
}

\section{KEYWORDS}

fed-batch, fermentative process, bioenergy, cassava starch wastewater.

\begin{abstract}
The hydrogen is a fuel with a high energy density. Studies have sought to verify the potential of different residues and configurations of reactors in the production of biohydrogen. This study evaluated the influence of the organic loading rate on the production of biohydrogen from cassava starch wastewater (CSW) in anaerobic sequencing batch biofilm reactors (AnSBBR) operated in a fed-batch. In the tests, the organic loading rates of $9.0 ; 13.5$ and $18.0 \mathrm{~g}_{\mathrm{CT}} \mathrm{L}^{-1} \mathrm{~d}^{-1}$ were used, at cycle times $(\mathrm{CT})$ of 4 ; 4 and $2 \mathrm{~h}$ (tests I, II and III, respectively). The reactor was inoculated with sludge from a pilot anaerobic reactor used in the treatment of CSW, heat treated (heated at $90^{\circ} \mathrm{C}$ for 15 min). With the increase of the organic load (condition I to II) with the same cycle time $(\mathrm{CT}: 4 \mathrm{~h})$, there were increases in the hydrogen molar productivity (PrM) and hydrogen yield in relation to applied total carbohydrate (RMCA) and removed (RMCR). However, with the increase in the organic loading rate in which the CT was reduced from 4 to $2 \mathrm{~h}$ (condition II to III), there was a decrease in PrM and RMCA and RMCR. The best performance of the reactor was verified in condition II (organic loading rate: $13.5 \mathrm{~g}_{\mathrm{TC}} \mathrm{L}^{-}$ ${ }^{1} \mathrm{~d}^{-1} ; \mathrm{CT}: 4 \mathrm{~h}$ ), in which the PrM was $35.8 \mathrm{molH}_{2} \mathrm{~m}^{-3} \mathrm{~d}^{-1}$ and RMCA and RMCR were 2.24 and $3.67 \mathrm{molH}_{2} \mathrm{~kg}_{\mathrm{TC}^{-1}}$, respectively.
\end{abstract}

\section{INTRODUCTION}

The hydrogen is considered a promising substitute for fossil fuels because it has a high energy density, but the techniques normally employed in its production, such as fossil fuel reform and water electrolysis, require high energy consumption. With this, the production of hydrogen through a biological process, from the fermentation of organic residues, is considered of interest, due to the abundance in the availability of these resources. According to Manssouri et al. (2013) and Lovato et al. (2015), the agroindustrial effluents have the potential for the production of biohydrogen in anaerobic reactor, due to its composition rich in carbohydrates.

Among the configurations of reactors for the production of biohydrogen, there are the anaerobic reactors operated in sequential batch with immobilized biomass (AnSBBR), in which the biofilm adheres to the surface of the inert support, predominantly, favoring the stability of the colonies (Lima et al., 2016).

Studies carried out in AnSBBR, for the production of hydrogen, have been conducted with wastewater based on glycerine and glucose (Bravo et al., 2015, Souza et al.,
2015) and some agroindustrial effluents, such as from Lima et al. (2016), with cheese serum, and Albanez et al. (2016), with vinasse and molasses in codigestion.

The west region of Paraná is characterized by intensive agroindustrial activity, among which the processing of cassava starch. The wastewater generated in this process has a high concentration of organic matter (Araujo et al., 2018), including compounds with high toxicity, such as linamarine, which is a cyanogenic glycoside responsible for blocking the respiratory chain of aerobic organisms. Generally, the wastewater from cassava processing industries is treated in anaerobic lagoons, which results in the release of greenhouse gases into the atmosphere and wide area requirements. According to Thanwised et al. (2012), this effluent rich in starch is a promising substrate for biotechnological processes, being able to obtain up to $10 \mathrm{~m}^{3}$ of biogas from $1 \mathrm{~m}^{3}$ of the wastewater. The cassava starch wastewater (CSW) is rich in organic matter of easy degradation, it can be considered a substrate with high potential for the biological production of hydrogen (energy generation), thus contributing to the sustainability of the starch production process.

\footnotetext{
${ }^{2}$ Universidade Estadual de Londrina/ Londrina - PR, Brasil.

${ }^{3}$ Universidade Estadual do Oeste do Paraná/ Cascavel - PR, Brasil

Received in: 4-27-2018

Accepted in: 8-16-2018
} 
The aim of this study was to evaluate the influence of the organic loading rate on the production of biohydrogen, from the cassava starch wastewater in AnSBBR operated in a fed-batch. The stability and performance of the reactor were evaluated through the indicators, yield and volumetric production of biohydrogen. The justification for the choice of the AnSBBR reactor in this study is to look for technological options for batch operation, as an alternative to continuous operation, aiming to obtain, technically, better operational control, low cost, easy cleaning, flexibility and suitability to the different compositions of wastewater.

\section{MATERIAL AND METHODS}

\section{AnSBBR with mechanical agitation}

The Figure 1 shows the scheme of the system used for the production of biohydrogen in AnSBBR. The reactor was made in Plexiglass ${ }^{\circledR}$, with the following dimensions: 5 $\mathrm{mm}$ of thickness, $30 \mathrm{~cm}$ of height, $20 \mathrm{~cm}$ in diameter, a total capacity of $6.0 \mathrm{~L}$ and a working capacity of $4.3 \mathrm{~L}$ (Manssouri et al., 2013; Albanez et al., 2016).

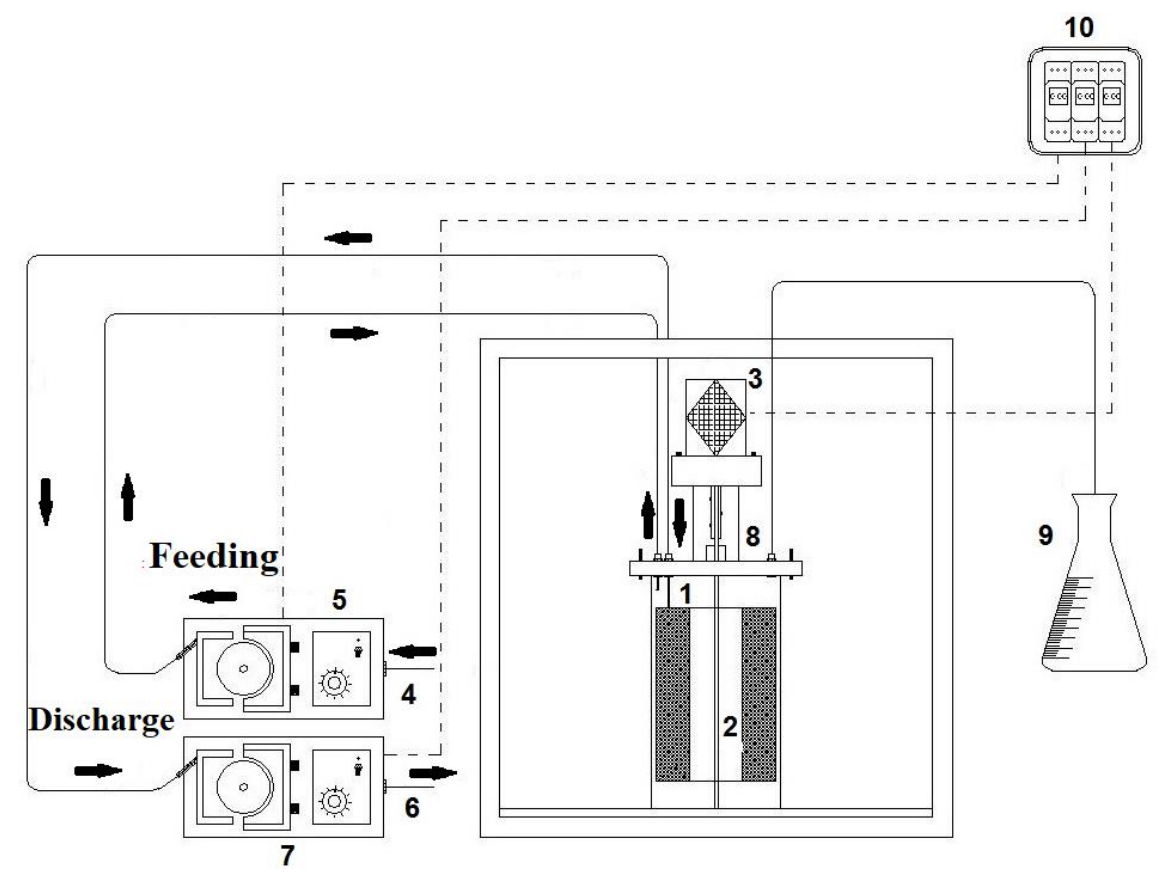

FIGURE 1 Schematic representation of the AnSBBR reactor: 1. Pexiglass ${ }^{\circledR}$ reactor; 2. Basket for biomass immobilization; 3. Agitation system; 4. Influent entrance; 5. Peristaltic pump metering input; 6. Effluent outlet; 7. Peristaltic discharge dosing pump; 8. Biogas output; 9. Biogas measurement system; 10. Automation system.

The support medium (polyethylene) was confined in a basket of perforated stainless steel, $18 \mathrm{~cm}$ of height, $7 \mathrm{~cm}$ of internal diameter and $17.5 \mathrm{~cm}$ of outside diameter. A lid of the same material was attached to the basket to prevent the biomass from leaving (Figure 2).

The mechanical agitation system consisted of turbine impellers (Michelan et al., 2009).

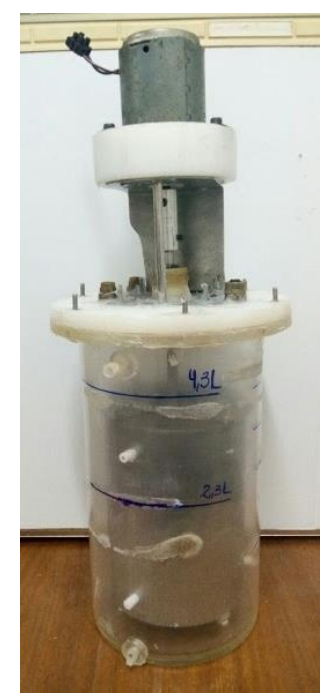

(a)

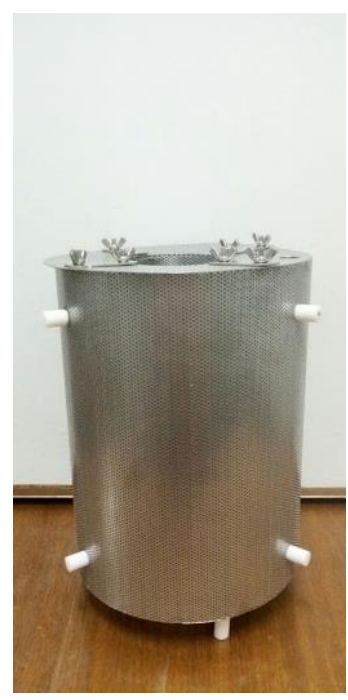

(b)

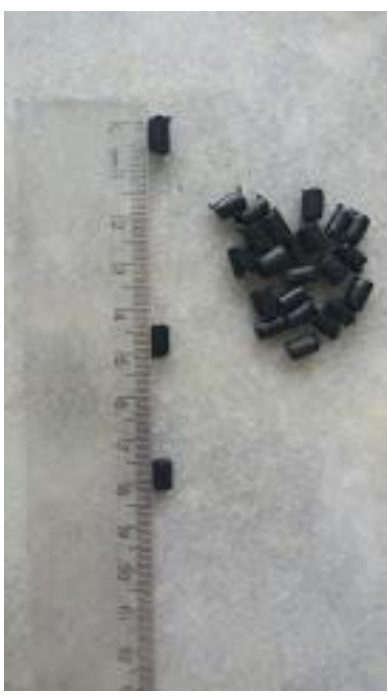

(c)

FIGURE 2. Images of the AnSBBR reactor. (a) reactor and agitation system; b) Basket for immobilization; c) Support material (low density polyethylene). 
In order to carry out the sequential batch (feeding, agitating and discharging) steps, Milan ${ }^{\circledR}$ brand metering peristaltic pumps, controlled by digital timers (TH-857 Plus Kienzle $^{\circledR}$ ), were used to control the activation/shutdown of pumps and the agitation system.

The volume of biogas produced daily was measured through a 3L Mariotte flask (Scoma et al., 2013) connected to the gas outlet, located in the upper part of the reactor and filled with water. In this system, the volume of liquid displaced corresponded to the volume of gas generated (Torres et al., 2017). The final volume was obtained after the correction for the normal conditions of temperature and pressure (NCTP) (Equation 1), where: $\mathrm{P}_{\mathrm{r}}$ corresponds to atmospheric pressure $(\mathrm{mmHg}) ; \mathrm{V}_{\mathrm{r}}$ is the volume of gas at the test conditions $(\mathrm{mL}) ; \mathrm{T}_{\mathrm{r}}$ is the temperature at which the reactor was subjected $\left({ }^{\circ} \mathrm{C}\right) ; \mathrm{P}_{\mathrm{NCTP}}$ is the atmospheric pressure at NCTP $(760 \mathrm{mmHg}) ; \mathrm{V}_{\mathrm{NCTP}}$ is the volume of gas in the NCTP $(\mathrm{mL}) ; \mathrm{T}_{\mathrm{NCTP}}$ represents the temperature in the $\operatorname{NCTP}\left(273 \mathrm{~K}-0^{\circ} \mathrm{C}\right)$.

$$
\frac{P_{r} \times V_{r}}{T_{r}+273}=\frac{P_{N C T P} \times V_{N C T P}}{T_{N C T P}}
$$

\section{Support material and inoculum}

In the biomass immobilization, the low-density polyethylene granules with a length of $5 \mathrm{~mm}$ were used (Figure 2c) (Lovato, 2014). The inoculum used in the AnSBBR was from a pilot scale anaerobic reactor installed to treat the effluent from the cassava starch industry. For the inoculation of the reactor under these conditions, the anaerobic sludge was subjected to a thermal pretreatment to eliminate the hydrogen-consuming microorganisms, which consisted in raising the temperature to $95^{\circ} \mathrm{C}$ for 15 minutes, as recommended by Sreethawong et al. (2010).

\section{Cassava starch wastewater (CSW)}

In order to carry out the experiment, the wastewater from the cassava starch extraction process was collected in industries located in the west of Paraná State, Brazil. The production process of cassava starch involves several stages and begins on the receiving until the extraction, where it is segregated in the processing and destination line of the solid residue (bagasse) and product transformation line (milk), where occurs the purification, concentration, dehydration, drying, bagging and, finally, obtaining the final product. The collected effluent is generated between the stages of milk up to the concentration and, within the industrial process, it is reused in the washing and peeling of cassava (Lucas, 2015).

Then, the residue was stored in $50 \mathrm{~L}$ gallons and transported to the laboratory and homogenized in a $300 \mathrm{~L}$ tank. After decantation of the coarse solids (soil, root parts and manioc peels), the effluent was bottled in $2 \mathrm{~L}$ bottles of polyethylene terephthalate (PET) and frozen at $-4,8^{\circ} \mathrm{C}$. The physical-chemical characterization occurred after decantation of the effluent. The parameters determined were: $\mathrm{pH}$, total carbohydrates, COD, total suspended solids, volatile suspended solids, Kjeldahl total nitrogen (KTN) and macro and micronutrients. For the accomplishment of this study, four collections of effluents were carried out in the industries (Table 1).

TABLE 1. Physical-chemical characterization of cassava starch wastewater.

\begin{tabular}{ccccc}
\hline & \multicolumn{4}{c}{ Conditions } \\
\cline { 2 - 5 } Parameters & I & II & III & IV \\
\cline { 2 - 5 } & Average & Average & Average & Average \\
\cline { 2 - 5 } pH & $4.56 \pm 0.24$ & $4.63 \pm 0.52$ & $4.73 \pm 0.71$ & $4.13 \pm 0.32$ \\
TC* & $4218.04 \pm 1164.6$ & $5012.20 \pm 1409.90$ & $4717.64 \pm 2331.5$ & $3047.65 \pm 800$ \\
COD $^{*}$ & $6270.02 \pm 1506.07$ & $9622.81 \pm 5206.22$ & $4843.44 \pm 900$ & $6519.42 \pm 987.72$ \\
KNT $^{*}$ & $1.50 \pm 0.49$ & $0.912 \pm 0.20$ & $0.67 \pm 0.65$ & $1.23 \pm 0.33$ \\
TSS $^{*}$ & $365.91 \pm 380.79$ & $311.38 \pm 100.13$ & $318.75 \pm 255.98$ & $180.85 \pm 54.56$ \\
VSS $^{*}$ & $337.32 \pm 356.11$ & $267.14 \pm 104.41$ & $312.91 \pm 189.27$ & $166.49 \pm 44.99$ \\
\hline
\end{tabular}

TC: total carbohydrates; * $\mathrm{mg} \mathrm{L}^{-1}$.

\section{Experimental Conditions}

Based on the study carried out by Manssouri et al. (2013), which operated an AnSBBR reactor fed with synthetic wastewater, we opted for the fed-batch feeding strategy. The experimental conditions and the methods used in the quantification of productivity and yield indicators were standardized according to the aforementioned author.

Table 2 shows the experimental conditions evaluated, whose feeding strategy was fed-batch, in which the feeding time consisted of $50 \%$ of the cycle time. The Conditions I, II, and III were operated for 12, 33 and 21 days, respectively. The end of each experimental condition was conditioned to the presence of hydrogen in the biogas. If after the three readings, on consecutive days, the hydrogen was not quantified in the sample, the assay was terminated and the reactor was discharged, cleaned and inoculated again to start the next condition. 
TABLE 2. Summary of the experimental conditions of the tests inoculated with anaerobic sludge.

\begin{tabular}{ccccccc}
\hline Condition & $\begin{array}{c}\text { Affluent concentration } \\
\left(\mathbf{m g} \mathbf{T}_{\mathbf{T C}} \mathbf{L}^{-\mathbf{1}}\right)\end{array}$ & $\begin{array}{c}\text { Cycle Time } \\
(\mathbf{h})\end{array}$ & $\begin{array}{c}\mathbf{N}^{\circ} \text { of cycles } \\
\mathbf{d}^{-\mathbf{1}}\end{array}$ & Time of filling (h) & $\begin{array}{c}\text { OLR } \\
\left(\mathbf{g}_{\mathbf{T C}} \mathbf{L}^{-\mathbf{1}} \mathbf{d}^{\mathbf{1}}\right)\end{array}$ & Inoculum \\
\hline I & 3500 & 4.0 & 6 & 2.0 & 9.0 & $\begin{array}{c}\text { Anaerobic } \\
\text { sludge }\end{array}$ \\
II & 5300 & 4.0 & 6 & 2.0 & 13.5 & $\begin{array}{c}\text { Anaerobic } \\
\text { sludge }\end{array}$ \\
III & 3500 & 2.0 & 12 & 1.0 & 18.0 & $\begin{array}{c}\text { Anaerobic } \\
\text { sludge }\end{array}$ \\
\hline
\end{tabular}

$\mathrm{TC}=$ total carbohydrates; OLR: Organic loading rate.

The organic loading rates were modified according to the affluent concentration and the cycle time ( 4 and $2 \mathrm{~h})$, setting 6 and 12 cycles daily. The initial $\mathrm{pH}$ of the cassava starch wastewater (CSW) was corrected to 6.0 with addition of sodium bicarbonate.

In the condition II, a feed sequence was started with $100 \%$ synthetic wastewater, followed by feeding with $50 \%$ synthetic wastewater (SW) and $50 \%$ of CSW, $30 \%$ of SW and $70 \%$ of CSW, until obtaining $100 \%$ of CSW, on the $24^{\text {th }}$ day. The gradual feeding with CSW was promoted in order to minimize losses to the performance of the reactor, considering that in the previous test, a decrease in the performance associated to the composition of the CSW had been observed. In this way, the gradual introduction of the real substrate could contribute to the proper acclimatization of the inoculum, thus assuring the hydrogen generation potential of the reactor.

\section{Analytical Methods}

The $\mathrm{pH}$ measurements were carried out in bench $\mathrm{pH}$ meter. The chemical oxygen demand (COD), total solids (TS), volatile solids (VS), total suspended solids (TSS), volatile suspended solids (VSS) and total nitrogen were determined by the methods recommended by the Standard Methods for the Examination of Water and Wastewater (Eaton et al., 2005).

The total alkalinity (TA) and total volatile acids (TVA) were determined according to the methodology proposed by Ripley et al. (1986). The total carbohydrate (TC) concentration was quantified according to the methodology of Dubois et al. (1956).

The determination of volatile fatty acids (acetic, butyric, propionic) and lactic acid were carried out using high performance liquid chromatography (HPLC) in Shimadzu ${ }^{\circledR}$ system equipped with Aminex ${ }^{\circledR}$ HPX-87H column (300 mm x $7.8 \mathrm{~mm}$ Bio- Rad), CTO-20A oven at $47^{\circ} \mathrm{C}$ temperature, $\mathrm{CBM}-20 \mathrm{~A}$ controller, UV detector with SPD-20A diode array at $208 \mathrm{~nm}$ of wavelength and LC20AT Pump. The mobile phase was composed of ultrapure water acidified with $0.005 \%$ of $\mathrm{H}_{2} \mathrm{SO}_{4}$, in a flow of $0.6 \mathrm{~mL}$ $\min ^{-1}$ and an injection volume of $20 \mu \mathrm{L}$ (Lazaro et al., 2012).

The collection of aliquots for the qualitative analysis of the biogas was carried out directly in the hose that connects the reactor to the gasometer. The constituents of the biogas (hydrogen, carbon dioxide and methane) were determined by gas chromatography in Shimadzu ${ }^{\circledR} 2010$ system equipped with Carboxen ${ }^{\circledR} 1010$ plot capillary column ( $30 \mathrm{~m}$ x $0.53 \mathrm{~mm} \times 0.30 \mu \mathrm{m})$. Dragging gas: argon; injector temperature: $200^{\circ} \mathrm{C}$; detector temperature: $230^{\circ} \mathrm{C}$; thermal conductivity detector (TCD); sample volume: 500 $\mu \mathrm{L}$; air flow of make-up (AR): $8 \mathrm{~mL} \min ^{-1}$; oven temperature program: initial temperature of $40^{\circ} \mathrm{C}(2 \mathrm{~min})$; $1^{\text {st }}$ heating rate: $5^{\circ} \mathrm{C} \mathrm{min}^{-1}$ until $60^{\circ} \mathrm{C} ; 2^{\text {nd }}$ heating rate: $25^{\circ} \mathrm{C}$ $\min ^{-1}$ until $200^{\circ} \mathrm{C}$; final temperature: $200^{\circ} \mathrm{C}(5 \mathrm{~min})$.

The molar concentration of hydrogen in the biogas was calculated through calibration curves. The number of moles of $\mathrm{H}_{2}$ in the sample was determined by the ideal gas equation (Equation 2), where: $\mathrm{P}$ corresponds to the atmospheric pressure (atm); $\mathrm{V}$ is the volume of gas injected $(500 \mu \mathrm{L}) ; \mathrm{n}$ is the number of moles; $\mathrm{R}$ is the universal constant of the ideal gases $\left(0.082 \mathrm{~atm} \mathrm{~L} \mathrm{~mol}{ }^{-1} \mathrm{~K}^{-1}\right)$ and $\mathrm{T}$ is the absolute temperature $(\mathrm{K})$ :

$$
P V=n R T
$$

\section{The reactor performance}

The reactor performance was evaluated based on the following response variables: removal efficiency of organic matter, molar productivity and molar yield of hydrogen.

\section{Removal Efficiency of organic matter}

The determination of the removal efficiency of organic matter in the form of COD or total carbohydrates in unfiltered and filtered samples $\left(\varepsilon_{\mathrm{B}}, \varepsilon_{\mathrm{F}}\right)$ were calculated by [eq. (3)] (Manssouri et al., 2013):

$$
\varepsilon_{B} \%=\frac{C_{A F L}-C_{E F L}}{C_{A F L}} \times 100
$$

That:

$\mathrm{C}_{\mathrm{AFL}}$ are the concentrations of $\mathrm{COD}$ or total carbohydrates in the affluent samples, and

$\mathrm{C}_{\mathrm{EFL}}$ refers to concentrations of $\mathrm{COD}$ or total carbohydrates in unfiltered (B) and filtered (F) effluent samples.

\section{Molar Productivity}

The molar productivity ( $\operatorname{PrM})$ is defined as the amount of biohydrogen $\left(\mathrm{H}_{2}\right)$ generated as a function of unit time and useful volume of the reactor $\left(\mathrm{molH}_{2} \mathrm{~m}^{-3} \mathrm{~d}^{-1}\right)$. The volumetric molar productivity was calculated according to [eq. (6)], where $\mathrm{nH}_{2}$ is the molar amount of hydrogen produced per day and $V_{R}$ is the total volume of wastewater in the reactor per cycle (Equation 4) (Manssouri et al., 2013):

$$
\operatorname{Pr} M=\frac{n_{H_{2}}}{V_{R}}
$$




\section{Molar yield}

The yield between the hydrogen produced and applied organic matter in the form of carbohydrates (RMCA) is defined as the amount of hydrogen produced $\left(\mathrm{molH}_{2}\right)$ as a function of the organic matter applied in $\mathrm{kg}$ of total carbohydrates (kgTC), expressed in molH $2 \mathrm{kgTC}^{-1}$. The calculation was performed according to [eq. (5)] (Manssouri et al., 2013):

$$
\mathrm{RMCA}=\frac{n_{\mathrm{H}_{2}}}{N x V_{A} x C_{A F L}}
$$

The yield between the hydrogen produced and removed organic matter in the form of carbohydrates
(RMCR) is defined as the amount of hydrogen produced $\left(\mathrm{H}_{2}\right)$ as a function of the organic matter removed in $\mathrm{kg}$ of TC expressed in $\mathrm{molH}_{2} \mathrm{kgTC}^{-1}$, calculated according to [eq. (6)] (Manssouri et al., 2013):

$$
\mathrm{RMCR}=\frac{n_{H_{2}}}{N x V_{A} x\left(C_{A F L}-C_{E F L}\right)}
$$

\section{RESULTS AND DISCUSSION}

\section{Reactor Performance}

Table 3 shows the values obtained for the performance indicators of the reactor under conditions I, II and III.

\begin{tabular}{|c|c|c|c|c|}
\hline \multirow{2}{*}{ Parameters } & \multirow{2}{*}{ Unit } & \multicolumn{3}{|c|}{ Conditions } \\
\hline & & I & II & III \\
\hline$\overline{\text { pH }}$ & & 4.56 & 4.63 & 4.13 \\
\hline TVA & mgHAc $L^{-1}$ & 1259.61 & 1745.03 & 1049.67 \\
\hline TS & $\mathbf{m g ~ L ^ { - 1 }}$ & 2886.84 & 4863.10 & 2597.92 \\
\hline TVS & $\mathrm{mg} \mathrm{L}^{-1}$ & 1957.05 & 3427.78 & 1991.46 \\
\hline TSS & $\mathrm{mg} \mathrm{L}^{-1}$ & 365.91 & 311.39 & 180.86 \\
\hline VSS & $\mathrm{mg} \mathrm{L}^{-1}$ & 337.32 & 267.14 & 166.50 \\
\hline Ecf & $\%$ & 95.66 & 97.79 & 94.93 \\
\hline Ecb & $\%$ & 97.79 & 98.06 & 90.60 \\
\hline ECODf & $\%$ & 24.21 & 23.97 & 16.33 \\
\hline ECODb & $\%$ & 27.39 & 35.45 & 24.00 \\
\hline
\end{tabular}

TABLE 3. The performance indicators of the reactor under conditions I, II and III.

$\varepsilon \mathrm{cb}$ : total carbohydrate consumption efficiency of crude samples; $\varepsilon$ cf: total carbohydrate consumption efficiency in filtered samples; $\varepsilon C O D b$ : removal efficiency of organic matter from raw samples; ECODf: removal efficiency of organic matter from filtered samples.

The maximum values of total carbohydrate consumption showed that, in most conditions, they were higher than $95 \%$ and only in condition III, both in the filtered and the crude form were approximately 94 and $90 \%$, respectively. The high consumption of total carbohydrate (> 90\%) shows that the microorganisms involved in the production of hydrogen easily assimilate the cassava starch effluent.

The removal of organic matter showed maximum values of approximately $20 \%$. Similar results were verified by Lima et al. (2013), Lima et al. (2016) and Albanez et al. (2016), who evaluated the organic matter removal in acidogenic reactors operated with synthetic medium based on glucose and sucrose; whey and vinasse/molasses, respectively. These authors also observed carbohydrate consumption above $84 \%$.

The high concentration of organic matter in the starch effluent facilitates the formation of intermediates such as alcohols and volatile acids (Lucas, 2015). In condition III, which was conducted with the highest organic loading rate $\left(18 \mathrm{~g}_{\mathrm{TC}} \mathrm{L}^{-1} \mathrm{~d}^{-1}\right)$, the lowest values of total volatile acids (TVA) were found, when compared to conditions I and II, which were conducted with the OLR of 9.0 and $13.5 \mathrm{~g}_{\mathrm{TC}} \mathrm{L}^{-1} \mathrm{~d}^{-1}$. The lowest value of TVA in condition III may be related to the concentration of lactic acid in the affluent, since this acid is not volatile. Inoue (2013) obtained TVA results similar to this study under conditions I and II, in evaluation of the biohydrogen production in AnSBBR, applying organic loading rate and filling time close to the ones adopted in this study $(9.0,13.5$, 18.0 and $\left.18.0 \mathrm{~g}_{\mathrm{COD}} \mathrm{L}^{-1} \mathrm{~d}^{-1}\right)$, but treating synthetic wastewater. Under these conditions, the author obtained TVA average values of 1057, 1465, 1566 and 1054 mgHAc $\mathrm{L}^{-1}$.

\section{Evaluation of intermediate products}

During the fermentation process, the lactic, acetic, propionic and butyric acids were quantified, which are derived from the conversion of organic matter, expressed as total carbohydrates. Table 4 shows the average concentrations of these intermediates (PI), for conditions I, II and III, in the affluent and effluent of the AnSBBR reactor.

TABLE 4. Average concentration of the intermediate products at the input and output of the reactor for conditions I, II and III.

\begin{tabular}{lllllll}
\hline PI $\left(\mathrm{mg} \mathrm{L}^{-1}\right)^{*}$ & \multicolumn{2}{c}{ Condition I } & \multicolumn{2}{c}{ Condition II } & \multicolumn{2}{c}{ Condition III } \\
\cline { 2 - 7 } & Input & Output & Input & Output & Input & Output \\
\hline Lactic Ac. & 2522.73 & 2439.61 & 2599.65 & 1756.61 & 1110.77 & 1882.60 \\
Acetic Ac. & 274.78 & 720.50 & 147.84 & 715.38 & 198.17 & 490.10 \\
Propionic Ac. & 0.00 & 297.21 & 0.00 & 622.39 & 0.00 & 258.28 \\
Butyric Ac. & 0.00 & 738.70 & 0.00 & 856.07 & 0.00 & 429.56 \\
\hline
\end{tabular}

*Average values 
The concentration of the organic acids in the affluent varied among the evaluated conditions, due to the differences in the composition of the residues collected in the industry. During the conduction of the tests, only the concentration of total carbohydrates was standardized.

Under conditions I and II, the concentration of lactic acid decreased in the reactor effluent, indicating that this metabolite may be used as a source of carbon by the microorganisms. In reactors fed with cassava processing residues, the metabolism of starch is conditioned by the breakdown into smaller sugars and, in this context, the lactic acid represents a readily available source of carbon (Baghchehsaraee et al., 2008). In condition III, on the contrary, there was an increase in the lactic acid concentration in the reactor effluent, probably due to the use of another metabolic pathway by the microorganisms, which promoted the production of the lactic acid. According to Yang et al. (2007), the production of hydrogen may be associated with some species of the Lactobacillus genus. In addition, Kawano et al. (2004) suggest that it is possible that these microorganisms coexist with bacteria of the Clostridium sp. genus in mixed cultures (Kawano et al., 2004).

In the literature, there are contradictory reports on the role of the bacteria producing lactic acid in the production of hydrogen. Baghchehsaraee et al. (2010) report some hypotheses in which different dynamics can be assumed from mixed inocula. In the first hypothesis, the bacteria producing lactic acid have inhibitory effects on the production of hydrogen; in the second, the lactic acidproducing bacteria may be associated with the production of hydrogen in small amounts; and the third is that, in fact, there is competition for the substrate between bacteria producing lactic acid and bacteria producing hydrogen, which would lead to an unstable system.
Theoretically, in the generation of the lactic acid and ethanol, there is no production or consumption of hydrogen. The rate of hydrogen can be calculated with the sum of the hydrogen produced by the fermentation of the acetic and the butyric acid (Alexandropoulou et al., 2018).

Generally, the production of hydrogen is related to the production of the butyric and acetic acids, which occur essentially at $\mathrm{pH}$ values between 4.0 and 6.0 (Chen et al., 2005). Higher concentrations of acetic acid would be desirable, since theoretically $4 \mathrm{~mol}$ of $\mathrm{H}_{2} \mathrm{~mol}^{-1}$ glucose is produced, while for the production of butyric acid, 2 mol of $\mathrm{H}_{2}$ mol $^{-1}$ glucose is formed. In general, the observed distribution of intermediate products was consistent with other studies (Antonopoulou et al., 2011).

Andreani et al. (2015) evaluated the production of hydrogen in a continuous anaerobic fixed bed reactor operating with cassava starch wastewater. The authors observed that, under the condition that the highest hydrogen production (1.1 $\left.\mathrm{L} \mathrm{d}^{-1} \mathrm{~L}^{-1}\right)$ was obtained, the butyric and acetic acids were the predominant metabolites in the fermentation process. In the AnSBBR reactor, higher concentrations of butyric acid $\left(856 \mathrm{mg} \mathrm{L}^{-1}\right)$ and acetic acid (715.54 $\mathrm{mg} \mathrm{L}^{-1}$ ) were observed in condition II. The fermentation processes with high concentrations of these acids may indicate the presence of Clostridium sp., which is the dominant genus in the microbiota during the $\mathrm{H}_{2}$ production phase (Nathao et al., 2013).

\section{Hydrogen production}

Table 5 shows the maximum values of the biogas flow rate $\left(\mathrm{V}_{\mathrm{G}}-\mathrm{mL} \mathrm{d}^{-1}\right)$, biogas composition in terms of $\mathrm{H}_{2}$ and $\mathrm{CO}_{2}$, hydrogen flow rate $\left(\mathrm{mL} \mathrm{d}^{-1}\right)$, molar productivity PrM $\left(\mathrm{molH}_{2} \mathrm{~m}^{-3} \mathrm{~d}^{-1}\right)$ and molar hydrogen yield relative to the applied and removed TC (RMCA and RMCR - $\mathrm{molH}_{2}$ $\left.\mathrm{kgTC}^{-1}\right)$, under conditions I, II and III.

TABLE 5. Indicators of hydrogen production for conditions I, II and III.

\begin{tabular}{|c|c|c|c|c|}
\hline \multicolumn{5}{|c|}{ Condition } \\
\hline Parameter & Unit & I & II & III \\
\hline $\mathrm{H}_{2}$ & $\%$ & 23.33 & 30.85 & 25.39 \\
\hline $\mathrm{CO}_{2}$ & $\%$ & 94.67 & 96.02 & 96.65 \\
\hline Volumetric production of Biogas & $\mathrm{mL}_{\text {biogas }} \mathrm{L}^{-1} \mathrm{~d}^{-1}$ & 36220.36 & 34012.56 & 16627.20 \\
\hline $\mathrm{H}_{2}$ flow & $\mathrm{mL} \mathrm{H}_{2} \mathrm{~d}^{-1}$ & 5276.16 & 10494.35 & 2344.98 \\
\hline PrM & $\mathrm{mol} \mathrm{H}_{2} \mathrm{~m}^{-3} \mathrm{~d}^{-1}$ & 27.61 & 35.79 & 9.18 \\
\hline RMCA & $\mathrm{mol} \mathrm{H}_{2} \mathrm{kgCT}^{-1}$ & 3.25 & 2.24 & 0.46 \\
\hline RMCR & $\mathrm{mol} \mathrm{H}_{2} \mathrm{kgCT}^{-1}$ & 2.03 & 3.67 & 0.56 \\
\hline
\end{tabular}

In tests I $\left(9.0 \mathrm{~g} \mathrm{~L}^{-1} \mathrm{~d}^{-1}\right)$ and III $\left(18 \mathrm{~g} \mathrm{~L}^{-1} \mathrm{~d}^{-1}\right)$, in which an affluent concentration of $3500 \mathrm{mg} \mathrm{L}^{-1}$ was applied, a production of hydrogen of 5.3 and $2.3 \mathrm{~L} \mathrm{~d}^{-1}$ was verified, with percentages of $\mathrm{H}_{2}$ in the biogas of 23.3 and $25.4 \%$, respectively. In test II $\left(13.5 \mathrm{~g} \mathrm{~L}^{-1} \mathrm{~d}^{-1}\right)$, the increase of the affluent concentration (5300 $\left.\mathrm{mg} \mathrm{L}^{-1}\right)$ increased the hydrogen production to $10.5 \mathrm{~L} \mathrm{~d}^{-1}$ with $\mathrm{H}_{2}$ levels in the biogas of $30.8 \%$. These results indicate that the higher cycle time (4 $\mathrm{h}$ ), the higher affluent concentration $\left(5300 \mathrm{mg} \mathrm{L}^{-1}\right)$ and the application of intermediate organic loading rate $\left(13.5 \mathrm{~g} \mathrm{~L}^{-1}\right.$ $\mathrm{d}^{-1}$ ) were more favorable to the production of hydrogen. According to Inoue et al. (2014), the increase in hydrogen production is directly related to the assimilation of the substrate by the microorganisms. Therefore, the substrate utilization can be maximized when the adjustment between the substrate availability (affluent concentration) and metabolic rates (cycle length) is achieved.

In condition II, the maximum value of PrM was approximately $36 \mathrm{~mol} \mathrm{H}_{2} \mathrm{~m}^{3} \mathrm{~d}^{-1}$ (Table 5). The hydrogen and PrM flow rates, in this condition, were higher in the last days of operation, indicating that the higher biogas production may be related to biomass growth. A similar trend was observed in the experiments performed by Manssouri et al. (2013), where the hydrogen yield was reduced when the cycle time decreased from $4 \mathrm{~h}\left(9 \mathrm{~g}_{\mathrm{TC}}\right.$ $\left.\mathrm{L}^{-1} \mathrm{~d}^{-1}\right)$ to $2 \mathrm{~h}\left(18 \mathrm{~g}_{\mathrm{CT}} \mathrm{L}^{-1} \mathrm{~d}^{-1}\right)$.

The maximum yield of hydrogen in relation to the total carbohydrate (TC) applied and removed was less than $4 \mathrm{molH}_{2} \mathrm{kgCT}^{-1}$, under all conditions, values similar to those obtained by Manssouri et al. (2013), Bravo et al. 
(2015) and Rosa et al. (2014). Among the conditions studied, the one with the highest values of hydrogen yield was the condition II, which was conducted with cycle time of $4 \mathrm{~h}$ and organic loading rate of $13.5 \mathrm{gL}^{-1} \mathrm{~d}^{-1}$.

Rosa et al. (2014) and Andreani et al. (2015), who worked with synthetic substrate, cheese whey and cassava starch effluent, respectively, in order to produce biohydrogen in different configurations and reactor types, present lower yield results than those achieved in this study, under conditions I and II.

Thus, in condition I to II there was an increase in hydrogen production related to the increase in organic loading rate, however, when the load from condition II to III increases, the performance decreased due to the restriction of cycle time.

\section{CONCLUSIONS}

The increase of the organic loading rate from 9 to $13.5 \mathrm{~g}_{\mathrm{TC}} \mathrm{L}^{-1} \mathrm{~d}^{-1}$, due to the increase of the total carbohydrate concentration (from 3500 to $5300 \mathrm{mg} \mathrm{L}^{-1}$ ), promoted an increase in molar productivity and hydrogen yield values in relation to the total carbohydrate applied and removed. The increase in organic loading rate from 13.5 to $18 \mathrm{~g}_{\mathrm{CT}} \mathrm{L}^{-1} \mathrm{~d}^{-1}$, due to the decrease in CT (from 4 to $2 \mathrm{~h}$ ), resulted in a decrease in molar productivity and hydrogen flow, probably due to the inhibition or to the change of metabolic routes of the hydrogen producing microorganisms. Considering the results obtained, in relation to hydrogen production in AnSBBR with cassava starch wastewater and fed-batch conduction, the conclusion is that the best operational condition was condition II (organic loading rate: $13.5 \mathrm{~g}_{\mathrm{CT}} \mathrm{L}^{-}$ ${ }^{1} \mathrm{~d}^{-1}$ and CT: $4 \mathrm{~h}$ ). In this condition, the molar hydrogen productivity was $35.79 \mathrm{molH}_{2} \mathrm{~m}^{-3} \mathrm{~d}^{-1}$ and the hydrogen yield in relation to the total carbohydrate applied and removed was 2.24 and $3.67 \mathrm{molH}_{2} \mathrm{kgTC}^{-1}$, respectively.

\section{ACKNOWLEDGMENTS}

The authors would like to thank the financial support from the National Council for Scientific and Technological Development (CNPq), case 428510/2016-7.

\section{REFERENCES}

Albanez R, Lovato G, Zaiat M, Ratusznei SM, Rodrigues JAD (2016) Optimization, metabolic pathways modeling and scale-up estimative of an AnSBBR applied to biohydrogen production by co-digestion of vinasse and molasses. International Journal of Hydrogen Energy 41:20473-20484.

Alexandropoulou M, Antonopoulou G, Trably E, Carrere H, Lyberatos G (2018) Continuous biohydrogen production from a food industry waste: Influence of operational parameters and microbial community analysis. Journal of Cleaner Production 174:1054-1063.

Andreani CL, Torres D G, Schultz L, Carvalho KQD, Gomes SD (2015) Hydrogen production from cassava processing wastewater in an anaerobic fixed bed reactor with bamboo as a support material. Journal of the Brazilian Association of Agricultural Engineering 35(3):578-587.
Antonopoulou G, Gavala HN, Skiadas IV, Beratos G (2011) Effect of substrate concentration on fermentative hydrogen production from sweet sorghum extract. International Journal of Hydrogen Energy 36:4843-4851.

Araujo IRC, Gomes SD, Tonelo TU, Lucas SD`M, Mari AG, Vagas RJ (2018) Tratamento de água residuária de fecularia e produção de biogás em reator anaeróbio de leito empacotado e fluxo contínuo. Journal of the Brazilian Association of Agricultural Engineering 38(2):270-276.

Baghchehsaraee B, Nakhla, G, Karamanev D, Margaritis A, Reid G (2008) The effect of heat pretreatment temperature on fermentative hydrogen production using mixed cultures. International Journal of Hydrogen Energy 33:4064-4073.

Baghchehsaraee B, Nakhla G, Karamanev D, Margaritis A (2010) Fermentative hydrogen production by diverse microflora. International Journal of Hydrogen Energy 35:5021-5027

Bravo ISM, Lovato G, Rodrigues JAD, Ratusznei SM, Zaiat M (2015) Biohydrogen production in an ANSBBR treating glycerin-based wastewater: effects of organic loading, influent concentration, and cycle time. Applied Biochemistry Biotechnology 1175:1892-1914.

Chen WM, Tseng ZJ, Lee KS, Chang JS (2005) Fermentative hydrogen production with Clostridium butyricum CGS5 isolated from anaerobic sewage sludge. International Journal of Hydrogen Energy 30:1063-1070.

Dubois M, Gilles KA, Hamilton JK, Rebers PA, Smith F (1956) Colorimetric method for determination sugars and related substance. Analytical Chemistry 28:350-356.

Eaton AD, Clesceri LS, Greenberg AE (2005) Standard methods for examination of water and wastewater. American Public Health Association 21:1600.

Inoue RK (2013) Influência da carga orgânica e do tempo de enchimento na produção de bio-hidrogênio em ANSBBR com agitação tratando água residuária sintética. Escola de Engenharia de São Carlos, Universidade de São Paulo.

Inoue RK, Lima DMF, Rodrigues JAD, Ratusznei SM, Zaiat M (2014) Effect of Organic Loading Rate and Fill Time on the Biohydrogen Production in a Mechanically Stirred AnSBBR Treating Synthetic Sucrose-Based Wastewater. Applied Biochemistry and Biotechnology 174:2326-2349.

Kawano T, Wada K, Li YY, Noike T (2004) Effect of substrate concentration and $\mathrm{pH}$ on hydrogen fermentation of mixed substrate by microflora. Water Environment 27:473-479.

Lazaro CZ, Vich DV, Hirasawa JS, Varesche MBA (2012) Hydrogen production and consumption of organic acids by a phototropic microbial consortium. International Journal of Hydrogen Energy 37:11691-11700.

Lima DMF, Moreira WK, Zaiat M (2013) Comparison of the use sucrose and glucose as a substrate for hydrogen production in an upflow anaerobic fixed-bed reactor. International Journal of Hydrogen Energy 38:1507415083. 
Lima DMF, Lazaro CZ, Rodrigues JAD, Ratusznei SM, Zaiat M (2016) Optimization performance of an AnSBBR applied to biohydrogen production treatingwhey. Journal of Environmental Management 169:191-201.

Lovato G (2014) Produção de bio-hidrogênio em AnSBBR tratamento efluente do processo de produção de biodiesel efeito da carga orgânica e do tempo de enchimento. Escola de Engenharia de São Carlos, Universidade de São Paulo.

Lovato G, Bravo ISM, Ratusznei SM, Rodrigues JAD, Zaiat M (2015) The effect of organic load and feed strategy on biohydrogen production in an AnSBBR treating glycerin-based wastewater. Journal of Environmental Management 154:128-137.

Lucas SDM (2015) Produção de hidrogênio e metano em reatores anaeróbios de leito fixo em série a partir de efluente de fecularia de mandioca. Centro de Ciência Exatas e Tecnológicas, Universidade Estadual do Oeste do Paraná.

Manssouri M, Rodrigues JAD, Ratusznei SM, Zaiat M (2013) Effects of organic loading, influente concentration, and feed time on biohydrogen production in a mechanically stirred AnSBBR treating sucrose-based wastewater. Applied Biochemistry and Biotechnology 1171:1832-1854.

Michelan R, Zimmer TR, Rodrigues JAD, Ratusznei SM, Moraes D, Zaiat M, Foresti E (2009) Effect of impeller type and mechanical agitation on the mass transfer and power consumption aspects of ASBR operation treating synthetic wastewater. Journal of environmental management 90(3):1357-1364.

Nathao C, Sirisukpoka U, Pisutpaisal N (2013) Production of hydrogen and methane by one and two stage fermentation of food waste. International Journal of Hydrogen Energy38(35):15764-15769.

Ripley LE, Boyle WC, Converse JC (1986) Improved Alkalimetric Monitoring for Anaerobic Digestor of HighStrength Wastes. Journal of Water Pollution Control Federation 58:406-411.
Rosa PRF, Santos SC, Sakamoto IK, Varesche MBA, Silva EL (2014) Hydrogen production from cheese whey with ethanol-type fermentation: Effect of hydraulic retention time on the microbial community composition. Bioresource Technology 161:10-19.

Scoma A, Bertin L, Fava F (2013) Effect of hydraulic retention time on biohydrogen and volatile fatty acids production during acidogenic digestion of dephenolized olive mill wastewaters. Biomass and Bioenergy 28:51-58.

Souza LP, Lullio TG, Ratusznei SM, Rodrigues JAD, Zaiat M (2015) Influence of Organic Load on Biohydrogen Production in an AnSBBR Treating Glucose-Based Wastewater. Applied Biochemistry and Biotechnology 176:796-816.

Sreethawong T, Chatsiriwatana S, Rangsunvigit $\mathrm{P}$, Chavadej S (2010) Hydrogen production from cassava wastewater using an anaerobic sequencing batch reactor: Effects of operational parameters, COD:N ratio, and organic acid composition. International Journal of Hydrogen Energy 35:4092-4102.

Torres GD, Lucas SDM, Andreani LA, Carvalho KQ, Coelho SRM, Gomes SD (2017) Hydrogen Production and Performance of Anaerobic Fixed-Bed Reactors Using Three Support Arrangements From Cassava Starch Wastewater. Journal of the Brazilian Association of Agricultural Engineering 37(1):160-172.

Thanwised P, Wirojanagud W, Reungsang A (2012) Effect of hydraulic retention time on hydrogen production and chemical oxygen demand removal from tapioca wastewater using anaerobic mixed cultures in anaerobic baffled reactor (ABR). International Journal of Hydrogen Energy 37:15503-15510.

Yang P, Zhang R, Mcgarvey JA, Benemann JR (2007) Biohydrogen production from cheese processing wastewater by anaerobic fermentation using mixed microbial communities. International Journal of Hydrogen Energy 32(18):4761-4771. 